Jurnla Syntax Imperatif: Jurnal Ilmu Sosial dan

Pendidikan

p-ISSN: 2721-2491 e-ISSN: 2721-2246

Vol.1, No. 4, September 2020

\title{
Optimasi Instagram Sebagai Media Penyampaian Pesan Dakwah
}

\author{
Ahmad Zaki Abdul Aziz \\ Program Studi Komunikasi dan Penyiaran Islam, Sekolah Tinggi Agama Islam (STAI) \\ Persis Bandung, Indonesia \\ E-mail: ahmadzakky23@gmail.com
}

\begin{abstract}
Abstrak
Di era yang serba digital ini, Instagram telah menjadi salah satu sosial media favorit dengan pengguna mencapai lebih dari 1 miliar orang. Oleh karena itu, Instagram merupakan pilihan cocok untuk perkembangan dakwah kita selaku da'i atau orang yang memiliki kompetensi khusus dibidang dakwah, tak sedikit pula yang sudah mencoba menyampaikan dakwah melalui media Instagram ini,. Penelitian ini merupakan penelitian deskriptif dengan pendekatan kualitatif. Akun Instagram Yayasan Dialog Islam Garuda Bandung (@dialog_islam) yang menggunakan Instagram dan menyiarkan pesan dakwah di Instagram. Tujuan penelitian ini adalah untuk mengetahui sebera efektif pengoptimalan fitur instagram dalam menyampaikan pesan dakwah. Adapun hasil dari penelitian ini yaitu Instagram memberikan banyak sekali manfaat sebagai media dakwah jika kita mampu mengoptimalkan fitur didalamnya, dengan cara 1) Pahami cara kerja Algoritma Instagram 2) Tentukan Niche (pasar spesifik) target audience kita 3) Buatlah konten yang menarik dan memberikan nilai nyata bagi audience 4) Tingkatkan hubungan keterkaitan atau engagement dengan audience 5) Manfaatkan fitur Instastory, Highligt, Instagram Live, Video dan IGTV 6) Berkolaborasi dengan Influencer atau sesama konten kreator. Serta kesimpulan dari penelitian ini, Instagram dapat dikatakan efektif sebagai media dakwah, jika digunakan dengan optimal, baik secara fitur dan pesan yang sesuai syariat Islam. Seperti pada akun@dialog_islam yang mulai memperluas dakwahnya pada kalangan milenial dengan membuat konten seputar hadits atau ayat yang menyinggung permasalahan kehidupan yang seringkali dialami oleh kaum milenial dan mengemasnya secara menarik, seperti kata-kata bijak/quotes.
\end{abstract}

Kata kunci: Pesan Dakwah; Instagram; Konten;

\section{Pendahuluan}

Agama Islam merupakan suatu kebenaran, maka Islam harus tersebar luas dan penyampaian kebenaran tersebut merupakan tanggung jawab umat Islam secara keseluruhan. Sesuai dengan misinya sebagai "Rahmatan Lil-'Alamin", Islam harus ditampilkan dengan wajah yang menarik supaya umat lain beranggapan dan mempunyai pandangan bahwa kehadiran Islam bukan sebagai ancaman bagi eksistensi mereka melainkan pembawa kedamaian dan ketentraman dalam kehidupan mereka sekaligus sebagai pengantar menuju kebahagian kehidupan dunia dan akhirat.

Dakwah adalah tugas yang diberikan kepada setiap Muslim. Sebagaimana terdapat dalam Al-Qur'an dan As-Sunnah Rasulullah SAW, kewajiban dakwah menyerukan, dan menyampaikan Agama Islam kepada masyarakat. Allah SWT telah menegaskan untuk menyebarkan dakwah, menyeru hanya kepada Allah SWT semata dengan penuh kesadaran dan keyakinan, seperti halnya amanat yang telah Rasulullah SAW emban, amanat ini termaktub dalam firman-Nya: 
"Dan hendaklah ada di antara kamu segolongan umat yang menyeru kepada kebajikan, menyuruh kepada yang ma'ruf dan mencegah dari yang munkar merekalah orang-orang yang beruntung”. (Q.S. Ali-imran 104) (Departemen Agama, 1989)

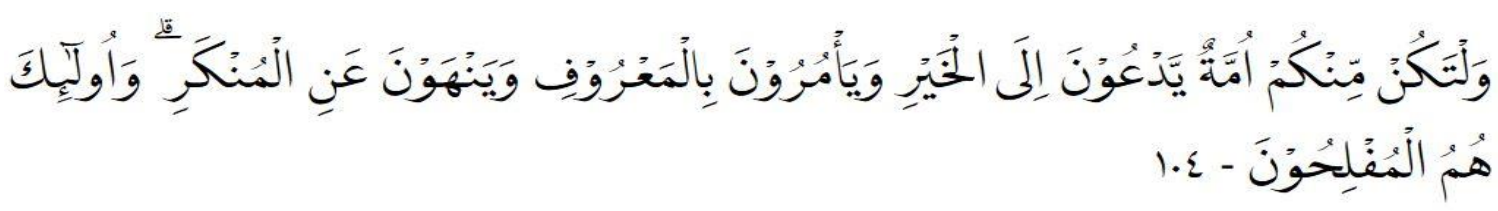

Sebagai seorang Muslim, baik itu pria maupun wanita berkewajiban untuk menyeru kepada kebaikan (Raqith, 2001, pp. 1-4), terlebih lagi jika kita memiliki kompetensi khusus mengenai detail dakwah dan hukum syari'ah, secara otomatis harus menjadi panutan bagi individu Muslim yang lain, karena kewajiban dakwah bukan semata-mata hanya bagi para ulama saja.

Dengan selalu berkembangnya teknologi maka dakwah bisa dilakukan dengan berbagai cara. Dakwah pada zaman sekarang ini tidak hanya harus disampaikan dalam setiap pengajian ataupun acara-acara peringatan hari raya Islam saja, dan tidak selalu bertempat pada masjid, majelis ta'lim maupun tempat ibadah Muslim lainnya.

Dalam penyampaian dakwah harus menggunakan media. Kemunculan berbagai macam media memberi kemudahan untuk menjangkau masyarakat secara luas. Media yang digunakan untuk berdakwah bermacam-macam, media audio yaitu media yang hanya menggunakan suara untuk didengarkan, media visual yaitu media yang menggunakan gambar dan tulisan yang hanya bisa dilihat, serta media audio visual media yang menggunakan suara dan gambar yang bisa dilihat dan didengar. Tentunya media audio-visual yang banyak digunakan saat ini untuk berdakwah lebih mudah dan cepat ditangkap oleh sasaran dakwah, melihat dan mendengar lebih berkesan daripada hanya melihat saja atau mendengar saja.

Salah satu media dakwah yang digunakan adalah media sosial, yang memberikan berbagai kemudahan, lebih cepat, dapat menyampaikan dakwah secara singkat, simpel dan luas. Peran media sosial dalam berdakwah kini juga menjadi sangat penting, melihat kondisi masyarakat khususnya Indonesia yang semakin banyak menggunakan media sosial.

Media sosial yang dapat digunakan untuk berdakwah salah satunya adalah Instagram. Instagram adalah salah satu aplikasi media sosial dari smartphone yang digunakan untuk membagi-bagikan foto dan video. Instagram sendiri masih merupakan bagian dari Facebook yang memungkinkan teman Facebook kita mem-follow akun Instagram kita. Makin populernya Instagram sebagai aplikasi yang digunakan untuk berbagi foto dan video membuat para Da'i dan Dai'yah turut membagikan pesan dakwahnya melalui Instagram.

Instagram merupakan salah satu media jejaring sosial yang dapat dimanfaatkan sebagai media dakwah, melalui Instagram-lah dakwah dibagikan dengan meg-upload 
video, sehingga para Mad'u dapat melihat dan mendengar pesan-pesan dakwah yang disampaikan melalui video atau foto yang dibagikan di Instagram.

Dialog Islam (@dialog_islam) adalah salah satu contoh akun di Instagram yang memanfaatkan instagram sebagi trend media dalam berdakwah dengan mengunakan foto dan video yang relate atau terjadi dan dialami langsung oleh kaum millennial terkait permasalahan kehidupan, serta aktif dalam mengadakan kajian secara streaming melalui platform lain selain Instagram.

\section{Metode Penelitian}

Dalam mencapai sebuah tujuan pasti menempuhnya melakukan berbagai cara atau metode. Metode penelitian adalah cara atau strategi menyeluruh untuk menemukan atau memperoleh data yang diperlukan. (Suhartono, 2002, p. 9)

Metode penelitian dari jenis tempat penelitian dilaksanakan maka penelitian ini digolongkan pada penelitian pustaka (library research). Penelitian kepustakaan adalah sebuah penelitian yang dilakukan dengan mengumpulkan data atau informasi dari berbagai kepustakaan baik yang terdapat di perpustakaan atau tempat lain seperti bukubuku, majalah, bahan dokumentasi, surat kabar, internet dan sebagainya. (Hariyati et al., 2016, p. 14)

Metode ini digunakan karena masalah yang diteliti merupakan masalah yang dapat diamati langsung, yakni yang berkaitan dengan pemanfaatan Instagram sebagai media penyampaian pesan dakwah.

\section{Hasil dan Pembahasan}

Di era yang serba digital ini, Instagram telah menjadi salah satu sosial media favorit dengan pengguna mencapai lebih dari 1 miliar orang. Oleh karena itu, Instagram merupakan pilihan cocok untuk perkembangan dakwah kita selaku $d a^{\prime} i$ atau orang yang memiliki kompetensi khusus di bidang dakwah.

Akan tetapi, tak sedikit pula yang sudah mencoba menyampaikan dakwah melalui media Instagram ini, namun penyampaiannya yang kurang efektif. Padahal sudah membuat konten, tetapi ternyata kontennya kurang menarik. Lebih parahnya, ditambah pula dengan minimnya pengetahuan tentang bagaimana konten yang diminati oleh audience atau mad'u itu sendiri. Sehingga engagement dari penyampaian dakwah tak kunjung meningkat atau malah hanya berjalan ditempat.

Dengan optimasi fitur Instagram ini, kita akan mempelajari dan lebih mudah memahami bagaimana dakwah yang efektif dengan memanfaatkan Instagram sebagai media penyampaian pesan dakwah dengan menyusun strategi yang sesuai dengan kondisi mad'u atau sasaran dakwah kita, agar menjadi Rahmatan lil 'alamiin atau bermanfaat bagi orang lain. (Digital.Marketer.id, 2020) 


\section{Memahami Algoritma Instagram}

Instagram adalah platform yang berorientasi pada bisnis. Hal ini penting untuk kita ingat bersama. Karena sebagai platform yang berorientasi pada bisnis, maka Instagram akan terus berubah dan tumbuh. Hal yang dapat memicu keberhasilan dalam Instagram beberapa waktu yang lalu, mungkin tidak berfungsi dengan baik pada hari ini. Ada pula strategi yang berjalan baik pada hari ini, akan tetapi tidak begitu efektif pada beberapa waktu yang lalu.

Maka dari itu kita dituntut untuk belajar cara berfikir dan strategi tentang Instagram, sehingga konten kita dapat dilihat dan mengundang engagement tanpa peduli pada perubahan yang terjadi pada platform Instagram.

Tujuannya adalah supaya kita dapat menyusun kerangka kerja untuk menciptakan strategi yang kokoh dalam penyampaian dakwah melalui media Instagram.

Kita mungkin pernah mendengar tentang "algoritma" akan tetapi masih bingung karena tidak tahu pasti apa algoritma itu sendiri. Secara sederhana, algoritma Instagram akan menentukan postingan mana yang akan dilihat oleh para pengguna Instagram dan kapan postingan itu akan ditampilkan.

Tidak seorangpun, kecuali orang-orang yang bekerja di media Instagram itu sendiri yang tahu betul bagaimana algoritma Instagram itu bekerja. Walaupun begitu, ada beberapa faktor kunci yang berperan dalam menentukan algoritma dalam menumbuhkan akun Instagram. Inilah diantaranya :

- $\quad$ Engagement (Like, Comment, dan Share)

Engagement adalah keterlibatan atau ukuran seberapa populer postingan Instagram kita bila dilihat dari jumlah orang yang menyukai (like), jumlah komentar, serta seberapa banyak posting kita dibagikan pada orang lain.

- Relevansi Konten

Relevansi konten adalah seberapa relevankah dari konten yang anda bagikan untuk mengundang interaksi dengan target audience atau mad'u.

\section{- Interaksi}

Instagram mengakui bahwa dengan siapa para pengggunanya terlibat, akan mempengaruhi tampilan feeds masing-masing pada Instagram mereka. Karena itu, sangat penting untuk berinteraksi dengan akun-akun dalam target audience atau $\mathrm{mad}^{\prime} \mathrm{u}$ kita

\section{- Konsistensi}

Instagram sangat merekomendasikan pada kita untuk membagikan konten setidaknya satu hari sekali. Namun tidak lebih dari dua kali sehari. Tentunya kita ingin konten yang kita bagikan tetap relevan dan menjadi peringkat teratas tanpa mengganggu pengguna lain (spamming).

- Pencarian Profil

Ini berarti akun mana yang sering dilihat atau kunjungi oleh para pengguna, juga akan mempengaruhi susunan feeds mereka. 
- Direct Share

Seberapa sering kita membagikan postingan (gambar atau video) dari akun lain, juga merupakan salah satu faktor kunci dalam algoritma Instagram.

\section{- Durasi atau Waktu}

Ialah seberapa lama durasi atau waktu yang dihabiskan oleh para pengguna untuk mencari dan melihat sebuah postingan atau konten yang kita bagikan.

Faktor utama yang mempengaruhi algoritma ialah dengan pengoptimalan keterlibatan posting (engagement) dan pentingnya dalam membangun hubungan yang kuat di Instagram.

\section{Menemukan Niche di Instagram}

Kita mungkin seringkali bingung dengan konten apa yang akan kita buat ketika baru saja membuat akun Instagram, dan ini merupakan kesalahan yang fatal jika kita tidak menentukan posisi dan tidak fokus pada industri yang kita pilih atau dengan kata lain kita tidak menentukan Niche sedari awal. Baik itu jika ingin mengembangkan akun Instagram kita, maupun pada pada platform lain.

Niche merupakan pasar spesifik dari target audience akun Instagram kita yang dapat mengarahkan kita terhadap tujuan atau goals kita. Karenanya, sangatlah penting untuk dapat menganalisa dan menentukan niche yang sesuai dalam mengembangkan akun Instagram kita.

Fungsi dari menentukan niche adalah supaya ketika membuat konten, kita memiliki arah yang jelas. Dalam menentukan niche, diperlukan 2 hal utama, yaitu passion atau keahlian kita, dan problem atau kebutuhan dari target audience kita, dan tidak ada salahnya pula jika kita menyisipkan unsur market didalamnya, agar kita dapat membuat karya yang menghasilkan dan menjawab kebutuhan market.

\section{Menentukan dan Membangun Engagement Mad'u}

Engagement merupakan faktor penentu apakah konten atau posting kita akan disupport oleh Instagram atau tidak, karena jika sistem Instagram men-support konten kita, maka kita akan memiliki kesempatan untuk menjangkau lebih banyak audience. Lantas bagaimana cara agar kita bisa mendapatkan engagement dari audience atau mad' $u$ target kita?

Agar konten kita dilirik oleh Instagram, alangkah baiknya mendapatkan banyak engagement pada 1 jam pertama posting. Rahasianya adalah kita harus membangun engagement terlebih dahulu dengan audience atau mad'u kita, baik sebelum dan sesudah posting.

Karena yang pertama kali akan melihat posting kita adalah followers, maka sebelum posting, kita juga harus berikan engagement pada postingan-postingan terbaru mereka. Berikan likes dan komentar yang bermakna, bukan asal sekedar berkomentar.

Setelah posting, lakukan hal serupa akan tetapi cobalah untuk mencari audience yang lebih luas, dengan cara mencari akun yang memiliki niche yang sama atau serupa 
dengan akun Instagram kita, serta berikan interaksi (like dan komentar) pada postingan terbaru mereka.

\section{Kurasi Konten Instagram}

Kurasi, atau istilah lainnya adalah mengumpulkan konten orang lain untuk kemudian diunggah ulang (repost) adalah salah satu cara yang dapat digunakan untuk pengenalan akun Instagram kita. Bila dilakukan dengan baik, maka kita berkesempatan untuk memanfaatkan konten buatan pengguna lain untuk mengangkat "brand" akun kita tanpa perlu menghabiskan banyak biaya.

Kurasi juga merupakan cara yang mudah untuk mendapatkan konten dengan kualitas bagus, selain itu konten yang di-kurasi juga memiliki kinerja yang cukup baik jika konten tersebut viral (konten bisa menjadi potensial jika konten yang di-kurasi merupakan konten yang viral) karena algoritma Instagram akan mengambil konten (foto atau video) yang diposting ulang. Maka dari itu, kita akan mendapat lalu lintas (traffic) tambahan dari memposting ulang konten yang viral.

Intinya, jika kita belum memiliki sarana yang memadai untuk membuat konten sendiri, maka kurasi konten bisa menjadi alternatif yang baik. Kita juga bisa mencampur antara kurasi konten dengan konten buatan kita sendiri, jadi jangan ragu untuk saling berbagi konten.

\section{Konten yang Memberi Nilai Nyata untuk Mad'u}

Kunci dari setiap konten Instagram adalah pengulangan dan konsistensi. Namun diluar itu, konten yang dibagikan juga harus memberikan nilai nyata untuk audience atau mad'u. Kita harus bisa menempatkan diri sebagai mereka (followers, audience atau mad'u), konten seperti apakah yang ingin kita lihat? Dengan begini, maka kita bisa membuat konten yang tidak hanya menarik bagi audience atau mad'u, namun juga bermanfaat untuk mereka. Berikut adalah jenis konten yang dapat menjadi ide untuk posting Instagram kita:

\section{- Promosi Produk}

Salah satu tujuan seseorang membuat akun Instagram adalah untuk meningkatkan "brand awareness" juga meningkatkan penjualan. Karenanya, jika kita ingin meningkatkan kesadaran audience pada akun Instagram kita harus mempublikasikan konten yang berfokus pada produk. Entah dalam bentuk gambar, video, maupun dalam bentuk media-media kreatif lainnya. Buatlah konten ini se-menarik dan se-menghibur mungkin sehingga audience tidak merasa jenuh dan terganggu dengan konten yang sebenarnya adalah iklan.

\section{- Informasi dan Tips}

Membagikan informasi dan tips seputar "brand" atau identitas akun Instagram kita, juga bisa menjadi konten yang mendatangkan audience karena dirasa bermanfaat bagi mereka. 
- Interaksi dengan Followers atau Testimoni

Kita juga bisa membagikan interaksi kita dengan followers kita, ataupun testimoni dengan konsumen produk kita, sebagai bukti integritas, kualitas dan penguatan "brand" serta menarik minat dan meningkatkan followers dan konsumen agar menjadi akun Instagram yang lebih terpercaya.

\section{- Kurasi Konten}

Seperti yang sudah dijelaskan sebelumnya, kita bisa pula memanfaatkan konten yang diunggah oleh audience dengan kurasi konten. Kita bisa mendorong followers atau konsumen produk kita untuk mengunggah konten dengan mempublikasikan produk atau hal yang berhubungan dengan "brand" kita. Kemudian kita unggah kembali konten tersebut secara berkala.

\section{- Quotes atau Pesan Inspiratif}

Seringkali, quotes atau pesan inspiratif juga mendapatkan respon baik dari audience. Namun jangan batasi kreatifitas kita, motivasi dan energi positif sebenarnya tidak hanya bisa disampaikan dengan kata-kata. Kita juga dapat mengunggah "meme", video lucu, ataupun konten-konten kreatif lainnya yang mungkin disukai oleh audience.

\section{Tahapan Funnel bagi Mad'u}

Setelah kita mengetahui cara membuat konten yang menarik, serta memahami apa saja yang diperlukan untuk merubah followers pasif menjadi engaged fans, sekarang mari kita pelajari bagaimana cara merubah halaman Instagram kita menjadi corong

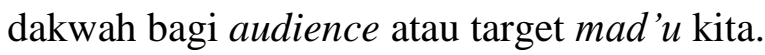

Hal ini hanya dapat dilakukan hanya jika kita telah benar-benar memahami target dakwah kita. Secara sederhana Tahapan Funnel ini adalah rangkaian proses yang terlebih dahulu dilalui oleh calon target dakwah kita sebelum memutuskan untuk benarbenar menjadi pengikut setia pada akun kita.

Lebih jelasnya ada 5 tahap yang mesti kita ketahui pertimbangan dibalik keputusan target dakwah kita sebelum menjadi pengikut setia :

\section{Awareness Stage (Tahap Kesadaran)}

Pada Tahap ini, calon target dakwah kita mengetahui brand/akun kita untuk pertama kalinya. Mereka bisa saja menemukannya dari Hashtag Instagram, atau mendapatkan referensi dari teman.

\section{Interest Stage (Tahap Ketertarikan)}

Pada tahap ini, calon target dakwah kita mulai mengikuti konten yang kita bagikan dan menunjukkan ketertarikannya dengan meninggalkan likes, komentar, atau bahkan membagikannya ulang (repost) mereka juga bisa jadi mencari tahu lebih lanjut tentang brand/akun kita dengan mengunjungi media/platform lain milik kita. 


\section{Evaluation Stage (Tahap Evaluasi)}

Kerja keras kita untuk membangun hubungan dengan audience atau mad'u akhirnya membuahkan hasil pada tahap ini. Karena pada tahap inilah calon target dakwah sudah tertarik untuk menjadi pengikut pada akun Instagram kita.

\section{Conversion Stage (Tahap Konversi)}

Pada tahap ini calon target dakwah memutuskan untuk menjadi pengikut setia akun Instagram kita dan merubah statusnya menjadi pengikut loyal, karenanya tahap ini disebut sebagai tahap konversi.

\section{Brand Advocates (Pengikut Setia)}

Ada satu tahap tambahan diluar tahapan yang telah disebutkan. Adalah tahapan yang merubah pengikut biasa menjadi pengikut yang loyal. Pada tahap ini pengikut tidak hanya tertarik pada akun Instagram kita, namun juga mengabarkan atau mempublikasikan akun Instagram kita kepada pengguna lainnya atau orang-orang disekitar mereka.

\section{Penggunaan Media Sosial Instagram}

Media sosial dekat dengan kehidupan sehari hari. Pengguna media sosial seolah menjadikan media sosial sebagai kebutuhan primer. Kini mereka menggunakan media sosial bukan hanya untuk bercakap-cakap atau sekedar melihat-lihat tetapi lebih dari itu mereka memanfatkan media sosial yang ada.

Menurut Arif Rohmadi, media sosial memiliki banyak manfaat diantaranya sebagai berikut: (Rohmadi, 2016, p. 2)

\section{Mendapatkan Informasi}

Banyak informasi yang dapat diperoleh melalui media sosial, seperti informasi beasiswa, lowongan pekerjaan, info seputar agama maupun hal-hal yang sedang trend yang dibicarakan banyak orang.

\section{Menjalin Silaturahmi}

Melalui sosial media, kita sebagai user atau pengguna dapat melakukan komunikasi meski dengan jarak yang berjauhan dengan pengguna lain sehingga terjalin silaturahmi, baik dengan orang baru, teman lama, bahkan kerabat dan keluarga.

\section{Kegiatan Sosial}

Melalui media sosial, pengguna dimudahkan dalam menggalang dana bantuan untuk kegiatan sosial, hal ini dikarenakan informasi tentang penggalangan bantuan dapat dilihat dari oleh banyak orang dalam waktu yang singkat. Sehingga semakin banyak orang yang terketuk hatinya maka bantuan yang diperlukan akan terpenuhi. 


\section{Branding}

Branding merupakan kumpulan kegiatan komunikasi yang dilakukan oleh suatu perusahaan agar brand (merk) yang mereka tawarkan dikenal. Dalam perkembangan saat ini, branding tidak hanya dilakukan oleh perusahaan saja, namun meluas sampai tingkat personal (perorangan) atau yang lebih dikenal dengan personal branding.

\section{Promosi}

Adanya sosial media memudahkan orang mempromosikan produk atau jasa yang dimiliki, jika dahulu untuk berjualan harus berada dipinggir jalan, sekarang dari rumah pun kita bisa berjualan dengan menggunakan media sosial.

\section{Dampak Penggunaan Instagram Sebagai Media Dakwah}

Sebagai media yang sedang trend dalam penggunaanya untuk menyampaikan pesan dakwah, akan mengundang banyak $d a^{\prime} i$ untuk berkontribusi dalam dakwah melalui Instagram. Semua media pada dasarnya diusahakan untuk dibuat secara sempurna. Setiap media memiliki kelebihan dan kekurangan jika dibandingkan dengan media-media yang lain. Dengan kelebihan dan kekurangan itu timbullah dampak yang akan dirasakan. Instagram memiliki dampak positif apabila dimanfatkan dengan baik, yaitu:

1. Dakwah melalui media Instagram merupakan alternatif dakwah selain dakwah secara langsung, bertatap muka.

2. Instagram merupakan media sosial yang paling banyak penggunanya di Indonesia. Hal ini menjadi peluang besar bagi kegiatan dakwah. Karena tujuan utama dakwah lewat media sosial adalah diakses (dibaca, dilihat dan didengar) oleh orang lain.

3. Sebagai salah satu media jejaring sosial, instagram cukup akrab bagi penggunanya, hal tersebut dimanfaatkan dalam kegiatan dakwah di instagram, baik $d a$ ' $i$ yang sudah profesional maupun $d a$ ' $i$ dadakan dapat menyampaikan dakwah dengan gaya sendiri ke Instagram yang ringan dan tidak terkesan menggurui. Begitu pula dari sudut mad'u dapat merasa rileks tidak dalam ruang yang formal karena tidak bertemu dan tatap muka. Sehingga terjadi feedback yang bersifat terbuka.

Akan tetapi, Instagram juga memiliki kekurangan dalam penyampaian dakwah, yaitu:

1. Memberikan dampak negatif apabila tidak dilakukan dengan baik-dan benar.

2. Dakwah yang dilakukan di Instagram mengurangi kontak langsung tatap muka antara $d a{ }^{\prime} i$ dan mad'u. 
3. Efek dari proses dakwah melalui instagram kurang bisa diamati secara maksimal, karena bersifat maya.

Banyak sekali fitur dari instagram yang bisa dijadikan media dakwah yang dapat kita ambil pelajarannya, seperti pesan dakwah yang disampaikan langsung fokus pada sasaran yang dituju, mudahnya akses pesan dakwah tanpa harus kesana-kemari, terlebih materi yang disampaikan juga dikemas dengan menarik dan membuat kita senang melihatnya.

\section{Kesimpulan}

Instagram dapat dikatakan efektif sebagai media dakwah, jika digunakan dengan optimal, baik secara fitur dan pesan yang sesuai syariat Islam. Seperti pada akun beberapa akun yang mulai memperluas dakwah pada kalangan milenial dengan membuat konten seputar hadits atau ayat yang menyinggung permasalahan kehidupan yang seringkali dialami oleh kaum milenial dan mengemasnya secara menarik, seperti kata-kata bijak/quotes. Secara keseluruhan dakwah di Instagram yang merupakan dakwah milenial mampu menciptakan dakwah yang inovatif yang mampu menarik perhatian followers untuk membagikan ke media sosial yang mereka miliki.

Walaupun kita belum fasih menjadi seorang $d a$ ' $i$ yang menyampaikan dakwah secara langsung kita dapat berdakwah melalui fitur yang bisa kita optimalkan di akun Instagram kita, karena pengguna Instagram ini sangatlah banyak, jadi dakwah kita bisa mengenai sasaran yang lebih banyak. Maka tak sedikit pula dari para $d a$ ' $i$ yang memanfaatkan Instagram sebagai media dakwah.

Setelah mengadakan penelitian, pengolahan data dan analisa data tercantum sesuai hasil wawancara observasi dan dokumentasi, maka penulis dapat menarik kesimpulan dari optimasi fitur Instagram yaitu, Pahami cara kerja Algoritma Instagram, tentukan Niche (pasar spesifik) target audience kita, buatlah konten yang menarik dan memberikan nilai nyata bagi audience, tingkatkan hubungan keterkaitan atau engagement dengan audience, manfaatkan fitur Instastory, Highligt, Instagram Live, Video dan IGTV, serta berkolaborasi dengan Influencer atau sesama konten creator. 
Optimalisasi Instagram Sebagai Media Penyampaian Pesan Dakwah

\section{BIBLIOGRAFI}

Departemen Agama, R. I. (1989). Alquran dan terjemahnya. Proyek Pengadaan Kitab Suci Alquran.

Digital. Marketer.id. (2020). Instagram For Bussines.

Hariyati, R. T. S., Yani, A., Eryando, T., Hasibuan, Z., \& Milanti, A. (2016). The Effectiveness and Efficiency of Nursing Care Documentation Using the SIMPRO Model. International Journal of Nursing Knowledge, 27(3), 136-142. https://doi.org/10.1111/2047-3095.12086

Raqith, H. H. (2001). meraih sukses Perjuangan Da’i.

Rohmadi, A. (2016). Tips produktif ber-social media. Elex Media Komputindo.

Suhartono, I. (2002). Metode Penelitian Sosial. Bandung PT. Remaja Rosdakarya. 